\title{
Dissociation of $\beta$-Adrenoceptor Numbers from mRNA Levels during Acute Ischemia in Rat Myocardium
}

\author{
Kiyoko Nakamura, Mitsumasa Ohyanagi* and Tadaaki Iwasaki \\ First Department of Internal Medicine, Hyogo College of Medicine, 1-1, Mukogawa-cho, Nishinomiya 663, Japan
}

Received August 22, 1996 Accepted October 15, 1996

\begin{abstract}
To explore alterations in messenger RNA (mRNA) for the $\beta$-adrenoceptor ( $\beta$-AR) in ischemic myocardium, we compared the mRNA levels for $\beta$-AR in ischemic and nonischemic myocardium by in situ hybridization using a radioisotope imaging system. We also compared these mRNA levels in ischemic and nonischemic myocardium with the number of the $\beta$-AR by radioligand binding assay. The mRNAs for $\beta$-AR were diffusely distributed in normal hearts. The level of mRNA detected by in situ hybridization was reduced by acute ischemia, whereas the number of $\beta$-AR was increased. Although the number of $\hat{\beta}$-AR was increased in the myocardium with one or three hours ischemia, the total function in $\beta$-AR-stimulatory $G$ protein-adenylate cyclase system was not changed. There is a discrepancy between $\beta$-AR mRNA and protein levels in the acute ischemic rat ventricular myocardium.
\end{abstract}

Keywords: $\beta$-Adrenoceptor, Ischemia, mRNA, In situ hybridization

Northern blot analysis is commonly used to quantitatively evaluate messenger RNA (mRNA) in organ tissues. In situ hybridization (ISH) with radioisotopes is used to examine the distribution of mRNA in tissues (1). We hypothesized that if a tissue section had a uniform thickness, quantitative comparison of mRNA distribution at different areas of the section would be possible with ISH. We have already reported that quantitative evaluation of mRNA for $G$ proteins in rat myocardium is possible and well-correlated with Northern blot analysis (2).

It has been demonstrated that the number of $\beta$ adrenoceptors ( 3 -AR) may increase $(3-6)$ or decrease (7) in the ischemic myocardium. However, the changes in the mRNA level for $\beta$-AR of the ischemic myocardium have not been investigated yet. Considering the important role of mRNA in the regulation of proteins, we quantitatively evaluated these changes using the ISH technique in rats with myocardial ischemia induced by coronary artery ligation. The results were compared to the changes in the number of $\beta-\mathrm{AR}$ at the protein level using radioligand binding assay.

\footnotetext{
* To whom correspondence should be addressed.
}

\section{MATERIALS AND METHODS}

\section{Coronary artery ligation}

Myocardial infarction was produced in 10-week-old male Wistar rats weighing $280 \pm 8 \mathrm{~g}$ (8). Rats were anesthetized with intramuscular injections of pentobarbital sodium $(50 \mathrm{mg} / \mathrm{kg}$ ) and then intubated and artificially ventilated with room air. After performing a left thoracotomy through the fourth intercostal space, a pericardiectomy was done, and a needle with a thread was inserted into the myocardium $2-3 \mathrm{~mm}$ away from the origin of the left coronary arteries. The thread through the cardiac muscle was loosely tied into an overhand knot. The two ends of the threads were placed outside of the body. The chest was closed, and the rats were removed from the respirator. Piperacillin sodium (100 mg) was administered intramuscularly. The rats woke up within 30-60 $\mathrm{min}$ after the operation and were maintained on standard rat chow and water ad libitum. All rats received humane care and were treated in accordance with the guidelines established by the Rules for Animal Experimentation of Hyogo College of Medicine. One week after surgery when the operative wound had healed, coronary occlusion was performed by tightening the thread. Of the 42 rats in the ischemic group, eight died within $3 \mathrm{hr}$ of occlusion. After 1 or $3 \mathrm{hr}$ of coronary artery occlusion, 
the hearts were removed. At that time, cyanosed regions in the left ventricular free wall induced by left coronary artery ligation were defined as ischemic regions and the septal walls were also defined as nonischemic regions. A sham operation was performed in an identical manner but without ligation of the coronary artery to serve as a nonischemic control.

\section{In situ hybridization}

The ISH was performed by the method of our previous study (2). The hearts of 1 -hr ischemia $(n=6), 3-h r$ ischemia $(n=6)$ and control rats $(n=6)$ were removed without contamination of RNase and immersed in $0.1 \mathrm{M}$ phosphate-buffered saline (PBS) with 4\% paraformaldehyde (PFA) for $30 \mathrm{~min}$ and then in $0.1 \mathrm{M}$ PBS with $15 \%$ sucrose for $30 \mathrm{~min}$ at $4^{\circ} \mathrm{C}$. The hearts were quenched for $10 \mathrm{sec}$ in liquid nitrogen-cooled isopentane. Ten- $\mu \mathrm{m}$-thick sections were cut at the papillary muscle level with a cryostat and then mounted in lysine-coated slides and stored at $-80^{\circ} \mathrm{C}$ for up to 14 days until ISH.

The slides were fixed in 4\% PFA in $0.1 \mathrm{M}$ PBS at room temperature for $10 \mathrm{~min}$, washed twice in $0.1 \mathrm{M}$ PBS for $5 \mathrm{~min}$, and then immersed in $0.1 \mathrm{M}$ PBS with glycine $(2 \mathrm{mg} / \mathrm{ml})$ for $5 \mathrm{~min}$. After two rinses in $2 \times \mathrm{SSC}(1 \times \mathrm{SSC}$ : $150 \mathrm{mM} \mathrm{NaCl}$ and $15 \mathrm{mM}$ sodium citrate) for $20 \mathrm{~min}$, dehydration/delipidation was performed with $50-100 \%$ ethanol and chloroform. After air drying, the slides were placed in a humid chamber (a covered plastic container lined with wet filter paper). The oligonucleotide probes for $\beta_{1}$-adrenoceptor $(\beta 1-A R)$ and $\beta$-actin were labelled with $\left[\alpha{ }^{3} \mathrm{P}\right] \mathrm{dATP}$ using a $3^{\prime}$ end labelling kit. Four microliters of the oligonucleotide probe and 100 :l incubation buffer $(50 \%$ formamide, $4 \times \mathrm{SSC}, 1 \times$ denhardts, $10 \%$ dextran sulfate, $250 \mu \mathrm{g} / \mathrm{ml}$ yeast tRNA, $500 \mu \mathrm{g} / \mathrm{ml}$ salmon sperm DNA, $6 \mathrm{mM}$ dithiothreitol) were added to each section on slides. The slides were incubated for $18-24 \mathrm{hr}$ at $37^{\circ} \mathrm{C}$. The slides were washed four times in prewarmed $1 \times \mathrm{SSC}$ at $55^{\circ} \mathrm{C}$ for $15 \mathrm{~min}$ each and washed once in $1 \times \mathrm{SSC}$ at room temperature for $1 \mathrm{hr}$. After the slides were dipped briefly in water and air dried, the radioactivity of these sections for $\beta$-AR and $\beta$-actin on the slides was imaged with a radioanalytic imaging system (Ambis, San Diego, CA, USA). They were then exposed to Kodak X-OMAT AR films for 1 or 2 days at $-80^{\circ} \mathrm{C}$.

The regions of interest (ROI) were the center of the free wall which served as the ischemic region and the center of the ventricular septum as the nonischemic region; these were analyzed as cpm (count A) with a radioanalytic imaging system. The area of ROI in the ischemic region was the same size of ROI in the nonischemic region. The adjoining sections, which were cut next to the sections hybridized by probes for $\beta$-AR and $\beta$-actin were treated with RNase before hybridization as negative controls for determinating the specificity of the hybridization signals. The ROI for the negative controls were similarly set in the free wall and ventricular septum of equal size (count B). The counts of ROI in ISH of $\hat{\beta}$-AR were determined by subtracting count $B$ from count $A$. For quantitative anal$y$ sis, the relative amounts of mRNA of ROI in the free wall or septum of the left ventricles (LV) of rats with 1 or $3 \mathrm{hr}$ of ischemia were expressed as a percentage of the counts of ROI in the free wall or septum of the sham operative controls, respectively.

\section{$\beta$-Adrenoceptor binding assay}

The hearts of 1 -hr ischemia $(n=6)$ and 3-hr ischemia $(n=6)$ were removed. The myocardium was homogenized for $30 \mathrm{sec}$ in $20 \mathrm{vol}$. of ice-cold buffer containing $0.25 \mathrm{M}$ sucrose, $5 \mathrm{mM}$ tris- $\mathrm{HCl}$ and $1 \mathrm{mM} \mathrm{MgCl}_{2}(\mathrm{pH}$ 7.4) using a Polytron (Type PT 20; Kinematica, Luzern, Switzerland) with the dial set at 7 . The crude homogenate was centrifuged at $400 \times \mathrm{g}$ for $10 \mathrm{~min}$, and the supernatant was centrifuged at $10,000 \times g$ for $10 \mathrm{~min}$. The resultant supernatant was centrifuged at $100,000 \times \mathrm{g}$ for $30 \mathrm{~min}$. The pellet was washed twice in cold incubation buffer $(50$ $\mathrm{mM}$ Tris- $\mathrm{HCl}$ and $10 \mathrm{mM} \mathrm{MgCl}_{2}, \mathrm{pH} 7.4$ ) to finally yield a crude fraction of myocardial cell membrane that contains $1 \mathrm{mg}$ protein in each milliliter. The protein concentration was determined by the method of Lowry et al. with bovine serum albumin as the standard (9). A crude fraction of myocardial cell membrane $(0.2 \mathrm{ml})$ was incubated in duplicate or triplicate for $20 \mathrm{~min}$ at $25^{\circ} \mathrm{C}$ with various concentrations $(100-400 \mathrm{pM})$ of ${ }^{125} \mathrm{I}$-iodocyanopindolol (ICYP: specific activity $2200 \mathrm{Ci} / \mathrm{mmol}$ ) in a total volume of $400 \mu \mathrm{l}$. The reaction was terminated with the addition of $5 \mathrm{ml}$ of ice-cold incubation buffer. The bound and free radioligands were then separated by rapid filtration over Whatman GF/F glass filters (Whatman Laboratory Products Inc., Clifton, NJ, USA) under reduced pressure. The filters were washed twice with $5 \mathrm{ml}$ of cold incubation buffer. The radioactivity retained on filters was counted in a liquid scintillation spectrometer (Tri-carb 3385; Packard Instrument Co., Inc., Downers, IL, USA). Specific binding was defined as the difference between total binding in the absence of $(d l)$-propranolol and nonspecific binding in the presence of $10^{-5} \mathrm{M}$ $(d l)$-propranolol. The specific binding of ${ }^{125} \mathrm{I}-\mathrm{ICYP}$ to the membranes was saturable. The Scatchard analysis demonstrated that there was a single class of site. The dissociation constant $\left(\mathrm{K}_{\mathrm{d}}\right)$ and the number of binding sites $\left(B_{\max }\right)$ for ${ }^{125}$ l-ICYP binding to the membranes were determined from Scatchard analysis of saturation isotherms. The specific binding activity was expressed as femtomoles per milligram of protein, and the $K_{d}$ was expressed as picomoles. 
Adenylate cyclase activity

The hearts were removed after ischemic interventions for 1 and $3 \mathrm{hr}(\mathrm{n}=5$ each). Adenylate cyclase activity was measured in the homogenates by the method of Salomon et al. (10). Adenylate cyclase activity was determined in a reaction mixture containing $50 \mu \mathrm{M}\left[\alpha{ }^{32} \mathrm{P}\right] \mathrm{ATP}, 2 \mathrm{mM}$ $\mathrm{MgCl}_{2}, 0.1 \mathrm{mM}$ EGTA, $1 \mathrm{mM}$ 3-isobutyl-1-methylxanthine, $5 \mathrm{mM}$ creatine phosphate, $0.4 \mathrm{mg} / \mathrm{ml}$ creatine kinase, $0.1 \mathrm{mM}$ cyclic AMP, $2 \mathrm{mg} / \mathrm{ml}$ BSA in $50 \mathrm{mM}$ triethanolamine $/ \mathrm{HCl}(\mathrm{pH} 7.4)$, in a total volume of 100 ill. Homogenates (15 $\mu \mathrm{g}$ protein per tube) were preincubated with the reaction mixture in the absence or presence of $40 \mathrm{mM}$ sodium fluoride or $10 \mu \mathrm{M}$ forskolin as indicated, for $4 \mathrm{~min}$ at $30^{\circ} \mathrm{C}$. Thereafter, labelled ATP was added and the adenylate cyclase reaction was continued for $10 \mathrm{~min}$ at $30^{\circ} \mathrm{C}$.

\section{Chemicals}

31-AR and $\beta$-actin oligonucleotide, and $3^{\prime}$ end labelling kit, $\left[\alpha{ }^{32} \mathrm{P}\right] \mathrm{dATP},{ }^{125} \mathrm{I}-\mathrm{ICYP}$, and $\left[\alpha^{-}{ }^{32} \mathrm{P}\right] \mathrm{ATP}$ were obtained from Dupont/New England Nuclear (Boston, MA, USA). Other materials and chemicals were obtained from commercial sources.

\section{Statistics}

Values are expressed as the mean \pm S.E.M. Data were analyzed by Student's unpaired $t$-test. Differences were considered significant at $\mathrm{P}<0.05$.

\section{RESULTS}

\section{In situ hybridization}

The mRNAs for $\beta$-AR and $\beta$-actin were distributed uniformly in normal hearts. There was no signal of ISH in the negative control that was treated with RNase. The counts of ROI in the negative controls did not differ from those of the background.

After $1 \mathrm{hr}$ of ischemia, levels of mRNA for $\beta$-AR de-

\section{$\beta$ - adrenoceptor}
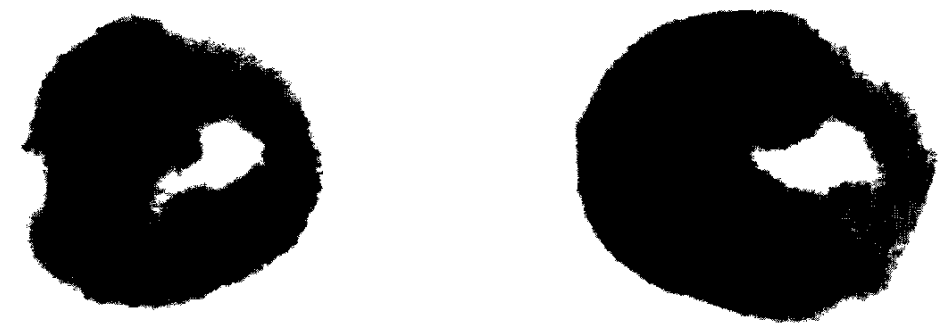

\section{$\beta-\operatorname{actin}$}
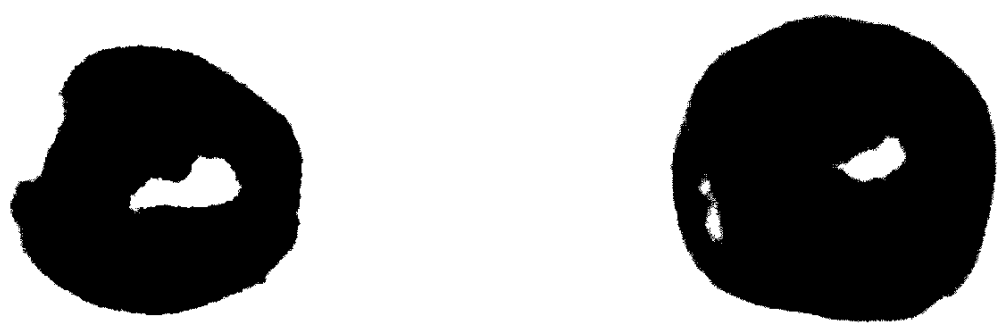

Fig. 1. Representative $X$ ray film images of in situ hybridization for $\beta$-adrenoceptor and $\beta$-actin in 1-and 3-hr ischemia rats. The left ventricular free wall is shown at the right side of each section. $1 \mathrm{~h}$ : 1 -hr ischemia rat, $3 \mathrm{~h}: 3$-hr ischemia rat. 
Table 1. mRNA for $\beta$-adrenoceptors and $\beta$-actin in the ischemic and nonischemic myocardium

\begin{tabular}{lccr}
\hline & n & $\beta$-Adrenoceptor & F-Actin \\
\cline { 1 - 3 } 1-hr ischemia & & & \\
$\quad$ Ischemic region (free wall) & 6 & $85 \pm 6^{*}$ & $98 \pm 7$ \\
$\quad$ Nonischemic region (septum) & 6 & $101 \pm 3$ & $101 \pm 5$ \\
3-hr ischemia & & & \\
$\quad$ Ischemic region (free wall) & 6 & $78 \pm 5^{*}$ & $103 \pm 10$ \\
$\quad$ Nonischemic region (septum) & 6 & $102 \pm 4$ & $101 \pm 9$ \\
\hline
\end{tabular}

Values are means - S.E.M. ${ }^{*} \mathrm{P}<0.05$ vs respective nonischemic myocardium. Values are expressed as a percentage of the counts in the free wall or septum in the sham-operated controls, respectively.

tected by ISH were substantially reduced in the ischemic region compared with the nonischemic region (Fig. 1). After $3 \mathrm{hr}$ of ischemia, reduction of mRNA levels for $\beta$ $A R$ in the ischemic region was more marked in comparison with the nonischemic region, and the areas of reduction of signal had spread more widely. In contrast, mRNA levels for $\beta$-actin did not differ between the ischemic and nonischemic region at both 1 and $3 \mathrm{hr}$.

\section{Quantitative analysis using ISH}

The mRNA levels for $\hat{\beta}$-AR in the nonischemic regions after 1 and $3 \mathrm{hr}$ of ischemia did not differ from those in the septal wall of the controls. In contrast, mRNA levels for $\hat{\beta}$-AR in the ischemic regions after $1 \mathrm{hr}$ were substantially reduced compared to the nonischemic regions $(\mathbf{P}<0.05)$ and after $3 \mathrm{hr}$ of ischemia, were also significantly reduced compared to nonischemic regions $(\mathrm{P}<0.05)$ (Table 1). Levels of those mRNA in ischemic regions after 1 and $3 \mathrm{hr}$ of ischemia were also significantly reduced compared to the free wall of the controls $(\mathrm{P}<0.05)$. The mRNA levels for $\beta$-actin in ischemic hearts did not differ from control hearts (data not shown).
Table 2. $\beta$-Adrenoceptors in the ischemic and nonischemic myocardium

\begin{tabular}{llccc}
\hline & $\mathrm{n}$ & $\begin{array}{c}\mathrm{B}_{\max } \\
\text { (fmol/mg protein) }\end{array}$ & $\begin{array}{c}\mathrm{K}_{\mathrm{d}} \\
(\mathrm{pmol})\end{array}$ \\
\cline { 1 - 1 } $\begin{array}{l}\text { 1-hr ischemia } \\
\text { Ischemic region (free wall) }\end{array}$ & 6 & $81 \pm 8^{*}$ & $348 \pm 176$ \\
$\quad$ Nonischemic region (septum) & 6 & $54 \pm 9$ & $319 \pm 154$ \\
3-hr ischemia & & & \\
$\quad$ Ischemic region (free wall) & 6 & $90 \pm 10^{*}$ & $339 \pm 151$ \\
$\quad$ Nonischemic region (septum) & 6 & $53 \pm 7$ & $350 \pm 175$ \\
\hline
\end{tabular}

Values are means \pm S.E.M. ${ }^{*} \mathrm{P}<0.05$ vs respective nonischemic region.

\section{$\beta$-Adrenoceptor binding assay}

After 1- and 3-hr ischemia, the numbers of $\beta-A R\left(B_{\max }\right)$ in the ischemic myocardium were significantly larger than those in the nonischemic myocardium $(\mathrm{P}<0.05)$. There were no differences in $K_{d}$ between ischemic and nonischemic myocardium after 1- and $3-\mathrm{hr}$ ischemia (Table 2).

\section{Adenylate cyclase activity}

Table 3 summarizes the results of analysis of adenylate cyclase activities in homogenates prepared from the ischemic regions and nonischemic regions after 1 and $3 \mathrm{hr}$ of ischemia. Basal adenylate cyclase activity were similar in the group with the ischemic regions vs nonischemic regions after 1 and $3 \mathrm{hr}$ of ischemia. There is no significant difference in cAMP contents after stimulation by isoproterenol between ischemic and nonischemic myocardium with 1- and 3-hr ischemia. Adenylate cyclase activity was significantly lower in sodium fluoride-stimulated samples from ischemic regions compared with nonischemic regions after 1 and $3 \mathrm{hr}$ of ischemia $(\mathrm{P}<0.05)$

Table 3. Changes in adenylate cyclase activities in the ischemic and nonischemic myocardium

\begin{tabular}{|c|c|c|c|c|}
\hline & \multirow{2}{*}{$\mathbf{n}$} & \multicolumn{3}{|c|}{ cAMP (pmol/mg protein $/ \mathrm{min}$ ) } \\
\hline- & & basal & isoproterenol & sodium fluoride \\
\hline \multicolumn{5}{|l|}{ 1-hr ischemia } \\
\hline Ischemic region (free wall) & 5 & $7.6 \pm 0.4$ & $14 \pm 6$ & $64 \pm 6^{*}$ \\
\hline Nonischemic region (septum) & 5 & $7.7 \pm 0.6$ & $18 \pm 4$ & $97=7$ \\
\hline \multicolumn{5}{|l|}{ 3-hr ischemia } \\
\hline Ischemic region (free wall) & 5 & $7.4 \pm 0.7$ & $12 \pm 5$ & $53 \pm 9^{*}$ \\
\hline Nonischemic region (septum) & 5 & $8.7 \pm 0.7$ & $19 \pm 4$ & $95 \pm 5$ \\
\hline
\end{tabular}

Values are means \pm S.E.M. ${ }^{*} \mathrm{P}<0.05$ vs respective nonischemic myocardium. 


\section{DISCUSSION}

The major findings of the present study were: 1) the distribution of $\beta$-AR mRNA was determined by ISH; 2) 1 and $3 \mathrm{hr}$ of ischemia resulted in a decrease in mRNA for $\beta$-AR; and 3 ) however, the number of $\beta$-AR was increased in ischemic myocardium.

We have already showed the distribution of $G$ protein (Gs and Gi) mRNA, as determined by ISH (2). We have showed that the counts of the negative controls were equal to the background count and that Northern blot analysis with the same end-labeled probe that was used in ISH resulted in band formation at each mRNA site. When the count of each mRNA in ROI was compared between ischemic and nonischemic areas, the result was identical to that obtained by Northern blot analysis. These findings indicate that ISH is a valid method for quantitative evaluation of mRNA distribution. Therefore, we evaluated $\beta$-AR mRNA in the ischemic myocardium using ISH. Since no appropriate antibody for $\beta$-AR for use in Western blot analysis was available, we measured the number of $\beta$-AR by radioligand binding assay.

Myocardial ischemia stimulates the sympathetic nerves, resulting in an elevation of blood catecholamine levels (11-13). In general, continuous stimulation by agonists induces the down regulation of receptors $(14-16)$. In our study, $\hat{\beta}$-AR mRNA in the myocardium with ischemia was decreased. This result suggests that agonist stimulation may induce down regulation of $\beta-A R$ at the mRNA level. At the protein level, however, the number of $\beta$-AR in the crude membrane was significantly increased in the ischemic myocardium as compared with the nonischemic myocardium. This result is consistent with that of many studies that showed an increase in 3-AR. Maisel et al. demonstrated an externalization of $\beta$-AR from an intracellular pool to a surface pool (17). Their study showed that ischemia was associated with an increase in receptor density in the sarcolemmal membrane fraction and with a concomitant decrease in the intracellular light-vesicle fraction. The mechanisms responsible for the redistribution of receptors remain unknown, but could include depletion of high-energy phosphate stores since the process of internalization of membrane receptors is energy dependent. However, they showed that the total number of 3 -AR in the sarcolemmal membrane fraction and in the intracellular light-vesicle fraction did not differ between the ischemic and nonischemic myocardium. These data suggest that the time intervals of 1 and $3 \mathrm{hr}$ may be not sufficiently long for these changes to occur at the protein levels even if the mRNA was decreased after 1-hr ischemia. In contrast, Hammond et al. demonstrated regional myocardial downregulation of $\hat{\beta}$-adrenoceptors in a porcine model of chronic episodic myocardial ischemia (5 weeks) without infarction or heart failure (18). Hadcock and Malbon showed that long term or high-dose agonist stimulation induced reduction in $\beta$-AR $\mathrm{mRNA}$ which plays an important role in the regulation of protein levels (19). This mechanism may play a role in the reduction of the number of $\beta$-AR in Hammond's animal models. Since the mRNA level was reduced in short ischemia ( 1 and $3 \mathrm{hr}$ ) in our study, it is suggested that the number of $\beta$-AR (protein level) could be decreased with longer periods of ischemia.

The mechanism for the decrease of $\beta$-AR after ischemia remains unclear. However, since $\hat{\beta}$-actin mRNA showed no changes even in the ischemic myocardium, the decrease in $\hat{\beta}$-AR is not attributable to ischemia-induced nonspecific changes. Our data also suggest that $\hat{\beta}$-actin mRNA is more resistant to ischemia compared to the mRNA for 3 -AR.

There was no difference in cAMP content after isoproterenol stimulation between the ischemic and nonischemic myocardium. The content of cAMP after sodium fluoride stimulation in the ischemic myocardium was smaller than that in the nonischemic myocardium. These data suggested that Gs function was decreased in the ischemic myocardium. This finding is consistent with that of our previous study (2).

In summary, the level of mRNA for $\beta$-AR detected by ISH was reduced by acute ischemia. Our findings suggest that acute myocardial ischemia may induce the downregulation of $\beta$-AR at the mRNA level. In contrast, the numbers of $\beta$-AR was increased. In acute ischemic myocardium, changes of $\beta$-AR monitored at the mRNA level are different from those determined at the protein level.

\section{REFERENCES}

1 Vincent SR, Hope BT, Drinnan SL and Reiner PB: G protein mRNA expression in immunohistochemically identified dopaminergic and noradrenergic neurons in the rat brain. Synapse 6 , 23-32 (1990)

2 Ohyanagi M, Yamamoto J, Nakamura K, Shibuya J, Morita M, Masutani M, Arii T and Iwasaki T: Messenger RNA for the guanine nucleotide-binding regulatory protein ( $G$ protein) is reduced in the acute ischemic myocardium. $\mathbf{J} \mathrm{Mol}$ Cell Cardiol 27, $1131-1139$ (1995)

3 Maisel AS, Ransnas LA and Insel PA: $\beta$-Adrenergic receptors and $G$ protein in myocardial ischemia and injury. Basic Res Cardiol 85, Supp 1, 47-56 (1990)

4 Mukherjee A, Wong TM, Buja LM, Lefkowitz RJ and Willerson JT: Beta adrenergic and muscarinic cholinergic receptors in canine myocardium. Effect of ischemia. J Clin Invest 64, 1423-1428 (1979)

5 Ohyanagi $M$, Matsumori $Y$ and Iwasaki T: $\beta$-Adrenergic receptors in ischemic and nonischemic canine myocardium: Relation 
to ventricular fibrillation and effects of pretreatment with propranolol and hexamethonium. J Cardiovasc Pharmacol 11, $107-114$ (1988)

6 Susanni EE, Manders WT, Knight DR, Vatner DE, Vatner SF and Homcy CJ: One hour of myocardial ischemia decreases the activity of the stimulatory guanine-nucleotide regulatory protein, Gs. Circ Res 65, 1145-1150 (1989)

7 Kiuchi K, Shen Y-T, Vatner SF and Vatner DE: Mechanisms mediating responsiveness to $\hat{j}$-adrenergic stimulation after coronary reperfusion in conscious dogs. Am J Physiol 267, H1578-H1588 (1994)

8 Morita M, Kawashima S, Ueno M, Kubota $A$ and Iwasaki $T$ : Effects of late reperfusion on infarct expansion and infarct healing in conscious rats. Am J Pathol 143, 419-430 (1993)

9 Lowry OH, Rosebrough NJ, Farr AL and Randall RJ: Protein measurement with Folin phenol reagent. J Biol Chem 193, $265-275$ (1951)

10 Salomon $\mathrm{Y}$, Londos C and Rodbell M: A highly sensitive adenylate cyclase assay. Anal Biochem 58, 541-548 (1974)

11 Schomig A: Catecholamine in myocardial ischemia: systemic and cardiac release. Circulation 82, Supp II, II-13-II-22 (1990)

12 Wollenberger $A$ and Shahab L: Anoxia-induced releases of noradrenaline from isolated perfused heart. Nature 207, 88-89 (1965)
13 Muntz K, Hagler HK, Boulas HJ, Willerson JT and Buja LM: Redistribution of catecholamines in the ischemic zone of the dog heart. Am J Pathol 114, 64-78 (1984)

14 Hausedorf WP, Caron MG and Lefkowitz RJ: Turning off the signal desensitization of $\bar{p}$-adrenergic receptor function. FASEB J 4, $2881-2889$ (1990)

15 Lohse MJ: Mechanisms of $\beta$-adrenergic receptor desensitization. In Signal Transduction in Photoreceptor Systems, Edited by Hargrave PA, Hofmann KP and Kaupp UB, pp 160-171, Springer-Verlag, Berlin (1992)

16 Hadcock JR and Malbon CC: Regulation of receptor expression by agonists: Transcription and posttranscriptional controls. Trends Neurosci 14, 242-247 (1991)

17 Maisel AS, Motulsky HJ and Insel PA: Externalization of $\beta$ adrenergic receptors promoted by myocardial ischemia. Science 230, $183-186$ (1985)

18 Hammond HK, Roth DA, McKiman MD and Ping P: Regional myocardial downregulation of the inhibitory guanosine triphosphate-binding protein $\left(\mathrm{Gi} \alpha_{2}\right)$ and $\hat{\beta}$-adrenergic receptors in a porcine model of chronic episodic myocardial ischemia. J Clin Invest 92, 2644-2652 (1993)

19 Hadcock JR and Malbon CC: Downregulation of ; 5 -adrenergic receptors: Agonist-induced reduction in receptor mRNA levels. Proc Natl Acad Sci USA 85, 5021 -5025 (1988) 